\title{
Perancangan Aplikasi Pengenalan Kendaraan Militer Dengan Augmented Reality Menggunakan Marker Based Tracking
}

\author{
Wahyu Satria Aji \\ Universitas Trilogi Indonesia \\ wahyuaji@trilogi.ac.id
}

\begin{abstract}
Abstrak
Perkembangan teknologi saat ini kian bervariasi dan memunculkan berbagai inovasi, salah satunya adalah penggunaan media auugmented reality. Teknologi augmented reality memadukan antara seni 2 dimensi dan 3 dimensi, dimana objek 2 dimensi menjadi sebuah marker yang nantinya akan menampilkan objek dalam bentuk 3 dimensi. Dalam penelitian ini membahas mengenai aplikasi augmented reality menggunakan prinsip marker based tracking untuk mengenalkan berbagai macam kendaraan militer yang ada, mengingatnya minimnya pengetahuan wawasan mengenai kendaraan-kendaraan menjadi salah satu alasan untuk melakukan penelitian ini. Aplikasi ini diimplementasikan sebagai media untuk membantu dalam melihat sekaligus mengenalkan berbagai macam objek kendaraan militer melalui sebuah media augmented reality. Pembuatan aplikasi ini menggunakan software Unity Engine versi 2019.2.16f1 yang dilengkapi dengan Vuforia SDK. Aplikasi ini dibuat melalui beberapa tahapan, diantaranya dimulai dengan perancangan UI aplikasi, lalu memasukkan objek 3 dimensi kedalam Unity Engine, pembuatan marker dengan Vuforia, dan tahapan yang terakhir adalah pengujian aplikasi menggunakan smartphone. Hasil aplikasi ini nantinya akan diimplementasikan dalam ekstensi (.apk) yang dapat digunakan di perangkat berbasis android. Diharapkan dengan adanya penelitian ini dapat menciptakan media yang menarik dengan augmented reality menggunakan marker based tracking untuk mengenalkan berbagai macam kendaraan militer yang ada.
\end{abstract}

Kata kunci: Kendaraan Militer, Augmented Reality, Marker Based Ttracking, Android

\section{APPLICATION OF MILITARY VEHICLE RECOGNITION APPLICATION WITH AUGMENTED REALITY USING MARKER BASED TRACKING}

\begin{abstract}
Current technological developments are increasingly varied and led to various innovations, one of which is the use of aungmented reality media. Augmented reality technology combines 2-dimensional and 3-dimensional art, where a 2-dimensional object becomes a marker that will later display objects in 3-dimensional form. This study discusses the application of augmented reality using the principle of marker based tracking to introduce a variety of military vehicles available, bearing in mind the lack of insightful knowledge about vehicles is one of the reasons for conducting this research. This application is implemented as a media to assist in viewing and introducing various types of military vehicle objects through an augmented reality media. The making of this application uses the Unity Engine software version 2019.2.16f1 which is equipped with Vuforia SDK. This application is made through several stages, including starting with designing the application UI, then inserting 3-dimensional objects into the Unity Engine, making markers with Vuforia, and the last stage is testing the application using a smartphone. The results of this application will be implemented in an extension (.apk) that can be used on Android-based devices. It is hoped that this research can create interesting media with augmented reality using marker based tracking to introduce a variety of existing military vehicles.
\end{abstract}

Keywords: Military Vehicles, Augmented Reality, Marker Based Tracking, Android 


\section{PENDAHULUAN}

Saat ini teknologi dibidang militer kian berkembang pesat khusunya di negara di Indonesia. Banyaknya perkembangan dari segi teknologi, fiturfitur yang tersedia kian menambah kecanggihan dari sebuah kendaran militer. Dengan adanya perkembangan tersebut nantinya dapat menunjang berbagai kebutuhan militer, baik pada saat latihan tempur maupun di medan perang.

Augmented Reality merupakan sebuah teknologi yang memadukan antara objek virtual dan objek nyata. Pemanfaatan teknologi Augmented Reality sangat bervariatif, mulai dari di bidang pendidikan, kedokteran, militer dan wisata. Teknologi AR banyak digunakan karena sifatnya yang interaktif, dimana pengguna dengan menggunakan kamera dari smartphone kemudian melakukan proses scanning kedalam sebuah marker, nantinya dari sebuah hasil scanning tersebut dapat memunculkan bentuk objek 3 dimensi[1].

Salah satu metode augmented reality yang digunakan dalam penelitian ini adalah Marker Based Tracking dimana metode ini menggunakan marker atau penanda untuk memunculkan objek maya kedalam bentuk nyata 3 dimensi [2].

Penelitian ini bertujuan untuk mengimplementasikan teknologi augmented reality sebagai media pengenalan kendaraan militer. Dimana diharapkannya dengan adanya aplikasi ini dapat membantu menambah wawasan pengetahuan mengenai beraneka ragamnya jenis dan model kendaraan militer yang ada. Selain itu dengan adanya aplikasi ini pengguna akan lebih interaktif, dan dapat meningkatkan minat dalam mempelajari dan mengenal berbagai macam kendaraan militer yang ada.

\section{METODE}

Metode yang digunakan dalam penelitian ini menggunakan metode SDLC(System Development

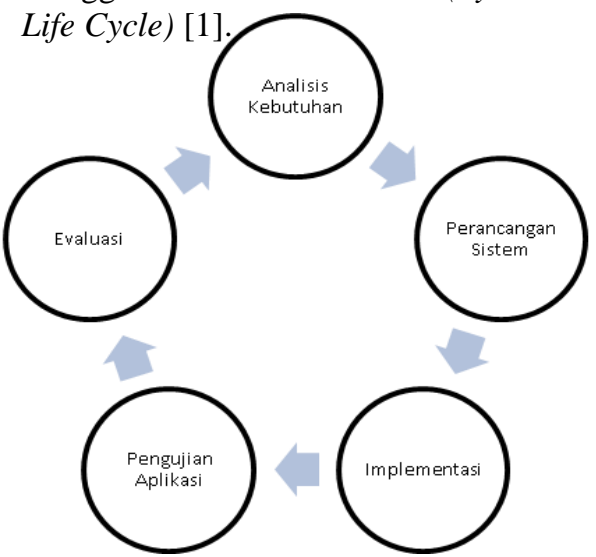

Gambar 1. Alur dari Metode SDLC
Dalam pembuatan aplikasi ini menggunakan metode SDLC yang terdiri dari analisis kebutuhan, perancangan sistem, implementasi, pengujian aplikasi dan evaluasi.

\subsection{Tahap Analisis Kebutuhan}

Dalam tahap analisis kebutuhan melakukan berbagai proses, diantaranya mencari informasi tentang kendaraan-kendaraan militer yang ada, kemudian objek 3 dimensi dari kendaraan militer tersebut yang didapatkan melalui internet dan buku ensiklopedia.

\subsection{Perancangan Sistem}

Pada tahap perancangan sistem setelah mengumpulkan berbagai data mengenai objek kendaraan militer, penulis membuat rancangan UI (user interface) tampilan aplikasi yang mudah dan menarik untuk digunakan.

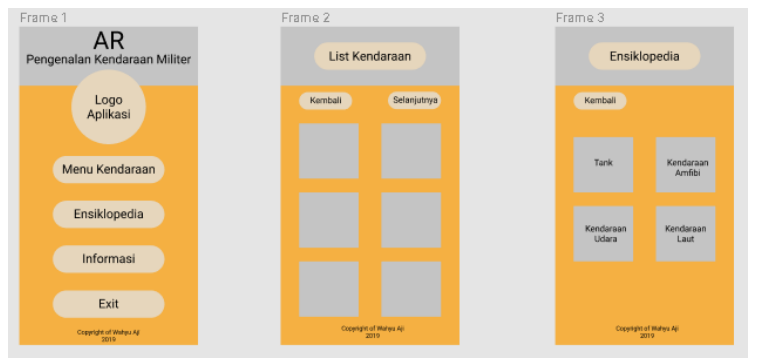

Gambar 2. Rancangan Aplikasi

Pada gambar 2 diatas merupakan hasil rancangan aplikasi oleh penulis dengan menggunakan Figma. Dari hasil rancangan tersebut terdapat 3 rancangan UI (User Interface) yang terdiri dari menu awal aplikasi yang terdiri dari logo aplikasi, dan button untuk mengarahkan ke menu lain aplikasi. Kemudian menu kedua adalah tampilan dari menu list kendaraan yang nantinya digunakan untuk menampilkan bentuk AR sesuai dengan gambar yang dipilih. Selanjutnya yang terakhir menu ensiklopedia berisi mengenai seputar informasi kendaraan militer sesuai dengan fungsinya masing-masing.

\subsection{Implementasi}

Pada tahap implementasi ini merupakan tahapan dimana penulis mengembangkan hasil rancangan menjadi sebuah aplikasi yang nantinya dapat digunakan. Pembuatan aplikasi 
ini dengan menggunakan Unity Engine versi 2019.2.16f1 yang di download dari Unity Hub [3] dan Vuforia SDK yang didownload melalui Asset Store Unity[4]

\subsection{Pengujian Aplikasi}

Pada tahapan pengujian aplikasi dilaksanakan ketika hasil dari implementasi sudah dilakukan. Pengujian dilakukan dengan 2 cara yaitu pengujian fungsional aplikasi, dan pengujian compatibility dan usability dari aplikasi[1].

\subsection{Evaluasi}

Pada tahapan ini merupakan tahapan evaluasi dari pengujian aplikasi. Jika masih terdapat beberapa kekurangan seperti tidak berfungsinya marker pada aplikasi, atau terjadinya bug/crash pada aplikasi, maka penulis akan memperbaiki aplikasi dan kembali melakukan tahapan pengujian aplikasi sampai aplikasi berfungsi dengan baik.

\section{HASIL}

Pada bagian ini membahas mengenai analisis kebutuhan, perancangan aplikasi, implementasi, dan pengujian aplikasi augemented reality dimana dalam pengembangan aplikasi ini menggunakan metode SDLC(Sistem Development Life Cycle).

\subsection{Analisis Kebutuhan}

Analisa kebutuhan aplikasi terdiri dari pembuatan alur sistem aplikasi yang digambar dengan diagram flowchart, kemudian pembuatan image target untuk kebutuhan aplikasi, dimana image target digunakan sebagai marker untuk nantinya menampilkan objek AR.

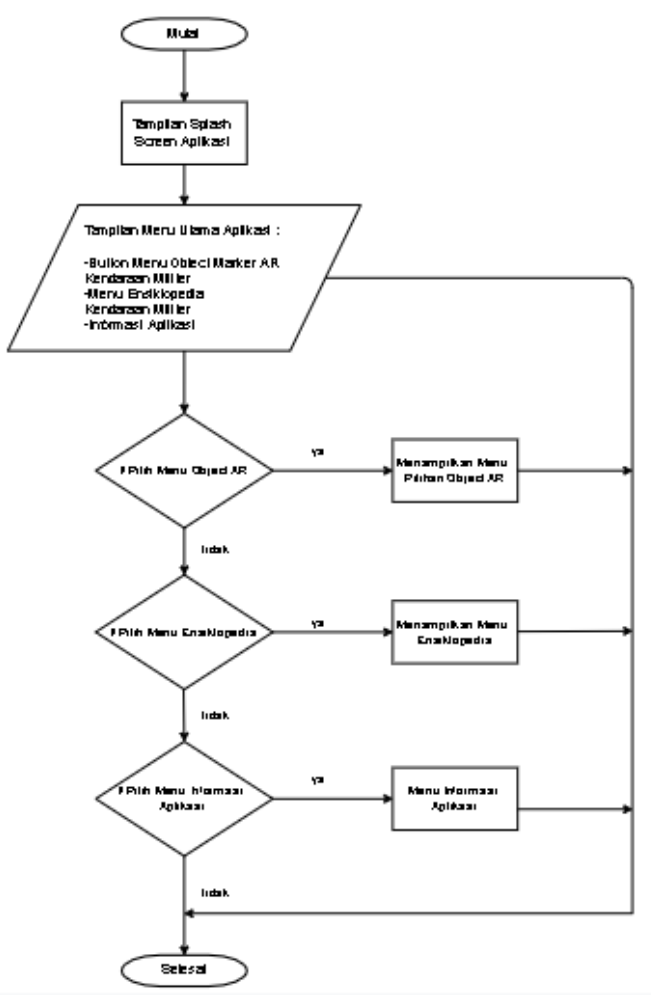

Gambar 3. Alur Flowchart dari Sistem Aplikasi

Pada Gambar 3 diatas dapat dilihat merupakan diagram flowchart dari aplikasi, dimana alur sistem yang pertama adalah menampilkan splash screen aplikasi, kemudian menampilkan menu utama yang tediri dari (menu objek AR, menu ensiklopedia, menu informasi aplikasi), dan tombol keluar aplikasi. 

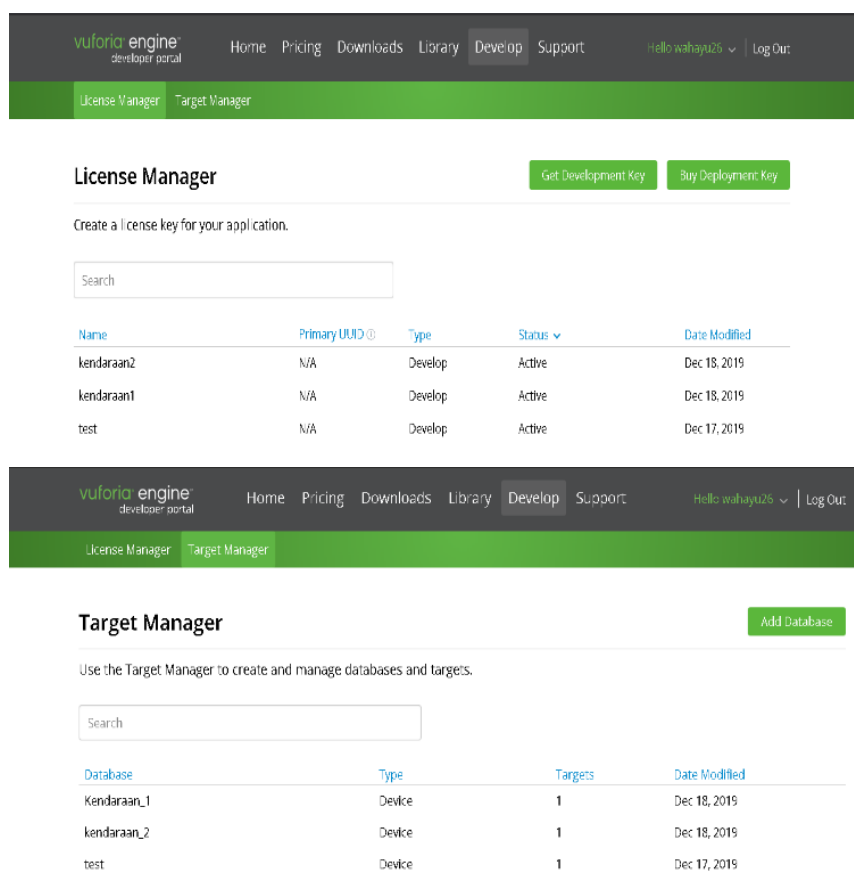

Gambar 4. Tampilan Website Vuforia Developer Portal

Pada Gambar 4 diatas merupakan tampilan halanan vuforia developer portal, dimana web tersebut digunakan untuk membuat objek image target yang nantiya digunakan untuk menampilkan objek AR pada aplikasi. Terdapat 2 langkah pada pembuatan image target untuk marker aplikasi, yang pertama penulis membuat license terlebih dahulu pada laman License Manager pada vuforia developer portal[5], kemudian menambahkan data base dimana untuk menyimpan objek gambar yang digunakan sebagai image target untuk menampilkan objek AR.

\subsection{Perancangan Sistem}

Selanjutnya pada perancangan sistem aplikasi, penulis memberi gambaran dari menu utama yang terdapat pada aplikasi, kemudian pembuatan permodelan objet 3D yang nantinya ditampilkan sesuai objek yang dipilih oleh pengguna.

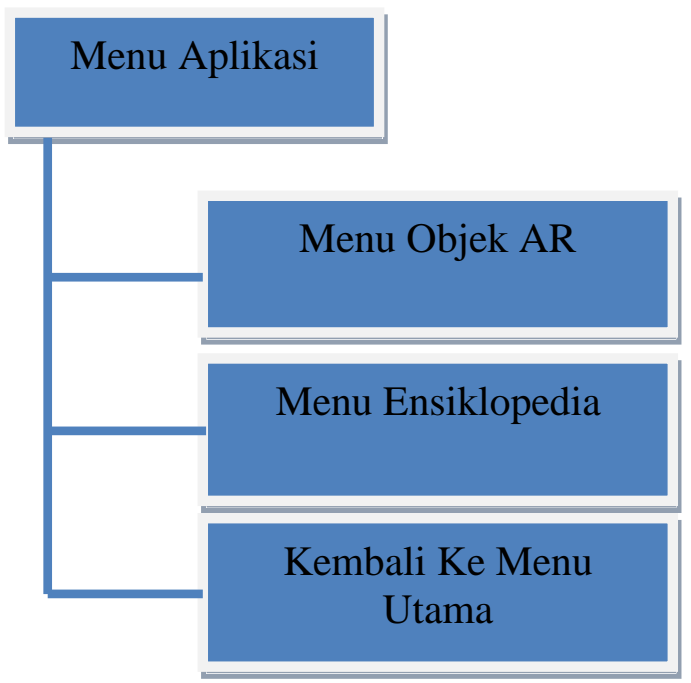

Gambar 5. Alur Rancangan Menu Aplikasi

Berdasarkan Gambar 5 merupakan rancangan dari alur menu utama pada aplikasi, yang terdiri dari tombol untuk menu pilihan object AR kendaraan militer, tombol menu ensiklopedia, tombol menu informasi aplikasi, lalu tombol keluar aplikasi.

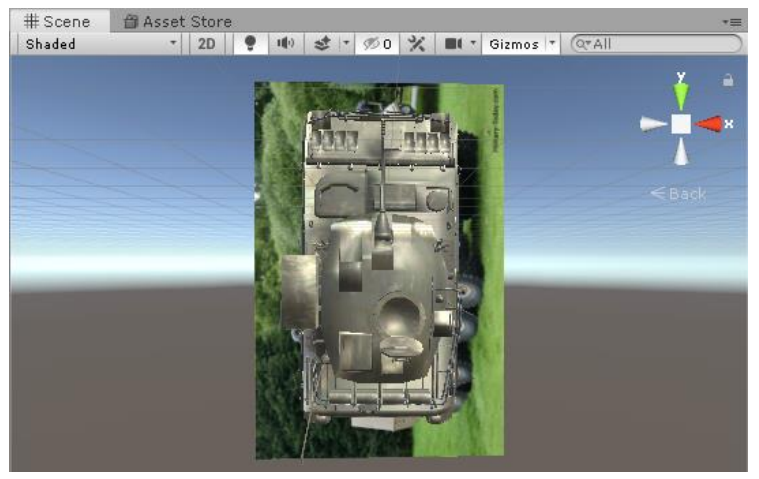

Gambar 6. Tampilan Target Model Object 3D 
Berdasarkan Gambar 6 diatas merupakan salah satu tampilan objek 3D yang nantiya akan ditampilkan oleh aplikasi. Objek yang ditampilkan sesuai dengan image target yang dibaca oleh AR Camera pada aplikasi

\subsection{Implementasi}

Pada tahap implementasi akan dijabarkan berbagai hasil implementasi dari perancangan sistem, implementasi target model 3D objek, dan hasil rancangan UI pada aplikasi.

\subsubsection{Halaman Utama Aplikasi}

Pada tahap berikut ini merupakan tampilan dari halaman utama pada apalikasi. Pada menu ini terdiri dari beberapa button yang memiliki fungsi untuk mengarahkan ke menu aplikasi lainnya, seperti button mulai untuk masuk ke menu aplikasi nantinya, kemudian button petunjuk untuk menampilkan langkah-langkah dalam menggunakan aplikasi, dan terakhir button keluar untuk menutup aplikasi. Berikut adalah hasil dari implementasi UI pada halaman utama aplikasi yang dapat dilihat pada Gambar 7 berikut.

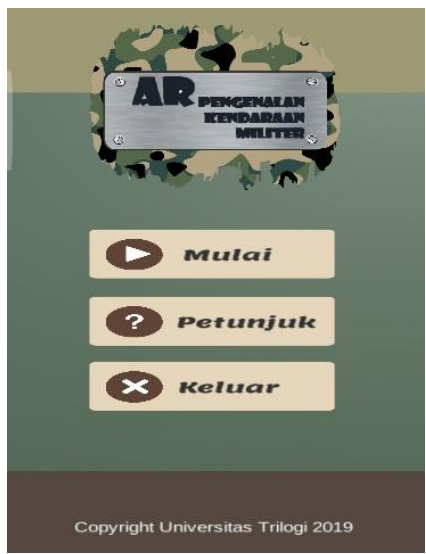

Gambar 7. Implementasi Halaman Utama Aplikasi

\subsubsection{Halaman Petunjuk Aplikasi}

Pada halaman ini berisi mengenai petunjuk penggunaan aplikasi. Berdasarkan Gambar 8 pada menu ini terdiri dari button, raw image dan juga text.

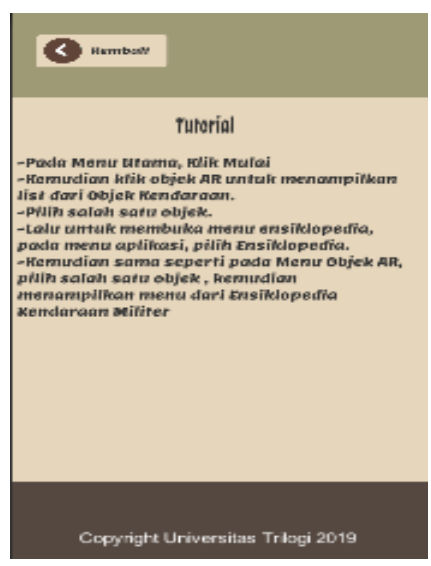

Gambar 8. Implementasi Tampilan Halaman Petunjuk Aplikasi

\subsubsection{Halaman Menu Aplikasi}

Pada halaman menu aplikasi berikut menampilkan tampilan UI yang terdiri dari beberapa button yang terdiri dari button untuk menampikan menu pilihan objek ar, button ensiklopedia, dan button untuk kembali ke menu utama pada aplikasi.

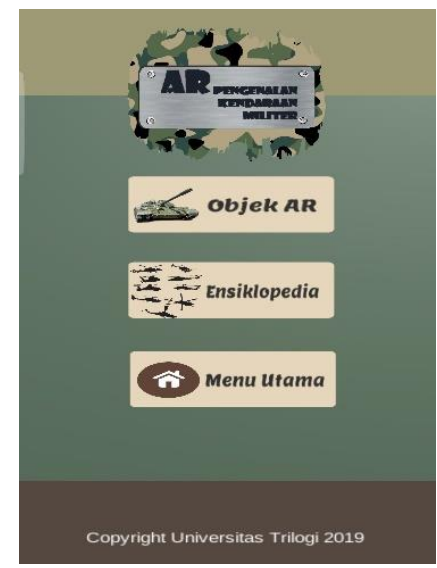

Gambar 9. Implementasi Menu Aplikasi

Pada Gambar 9 diatas menampilkan desain UI dari menu aplikasi yang dirancang menggunakan beberapa fitur seperti button dan raw image dari Unity Engine, kemudian dari masing-masing button tersebut diberikan fungsi OnClick agar button dapat berfungsi dan mengarahkan menu-menu lainnya.

\subsubsection{Halaman Pilihan Objek AR}

Pada tahap berikut menampilkan menu pilihan objek AR. Dari pilihan objek tersebut masing-masing memiliki objek yang berbeda- 
beda yang nantinya ditampilkan sesuai dengan image-target yang dimiliki oleh objek tersebut.

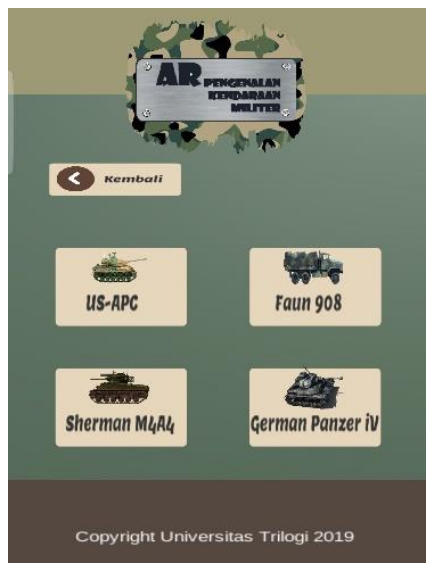

Gambar 10. Implementasi Menu Pilihan Objek AR

Pada Gambar 10 diatas hasil implementasi dari halaman pilihan objek AR pada aplikasi. Tampilan UI dari menu ini terdiri dari beberapa button dan raw image, dimana masing-masing button memiliki model gambar yang berbeda-beda dan nantinya akan menampilkan objek AR sesuai dengan yang dipilih oleh pengguna.

\subsubsection{Halaman Ensiklopedia}

Pada tahap berikut menampilkan menu yang menampilkan halaman ensiklopedia aplikasi. Pada tampilan ini menampilkan pilihan ensiklopedia dari objek-objek kendaraan militer yang ditampilkan pada objek AR aplikasi. Menu ini berisi mengenai berbagai informasi seputar kendaraan militer
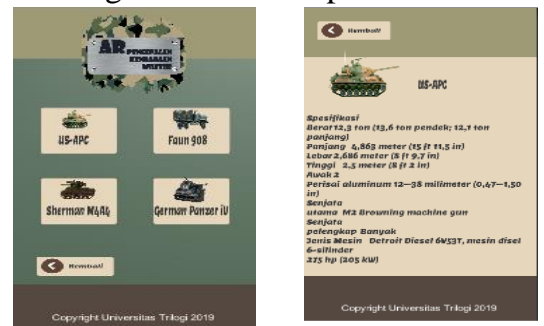

Gambar 11. Implementasi Menu Ensiklopedia

Pada Gambar 11 diatas menampilkan UI dari menu ensiklopedia yang dirancang dari beberapa fitur button, raw image, serta text. Dari masing-masing button kendaraan tersebut nantinya akan menampilkan halaman informasi kendaraan sesuai dari objek yang dipilih.

\subsubsection{Implementasi Objek AR}

Pada tahap berikut merupakan hasil implementasi augmented reality pada aplikasi. Pada menu ini akan menampilkan AR Camera yang nantinya menampilkan objek AR dalam bentuk 3D berdasarkan hasil scanning image-target dari AR Camera tersebut.

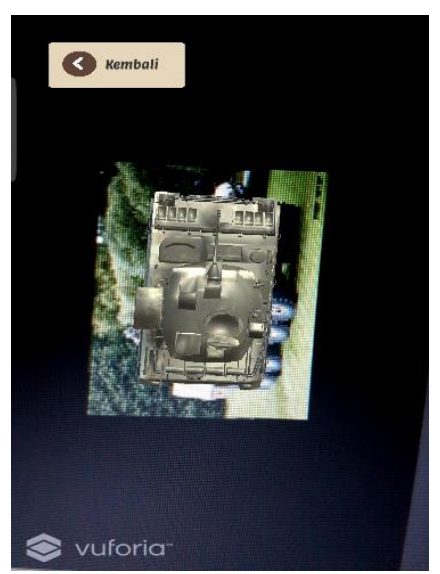

Gambar 12. Implementasi Objek AR Pada Image Target

Pada Gambar 12 diatas merupakan bentuk implementasi augmented reality. Pada menu tersebut terdiri dari AR Camera yang berfungsi untuk menampilkan objek AR, dan button kembali yang berfungsi untuk kembali ke menu sebelumnya.

\subsection{Pengujian Aplikasi}

Pada tahap pengujian aplikasi dilakukan dengan menggunakan metode pengujian fungsional dan pengujian compability dan usability[1].

Pengujian ini dilakukan untuk mencoba setiap fungsi button dan setiap menu untuk menampilkan objek AR apakah sudah berfungsi dengan baik.

Dari Tabel 1 dibawah ini merupakan hasil dari pengujian aplikasi untuk menampilkan setiap menu pada aplikasi. 
Tabel 1. Hasil Pengujian Aplikasi Pada Tiap Halaman berjalan di Android yang memiliki sistem operasi Jellybean 4.1.

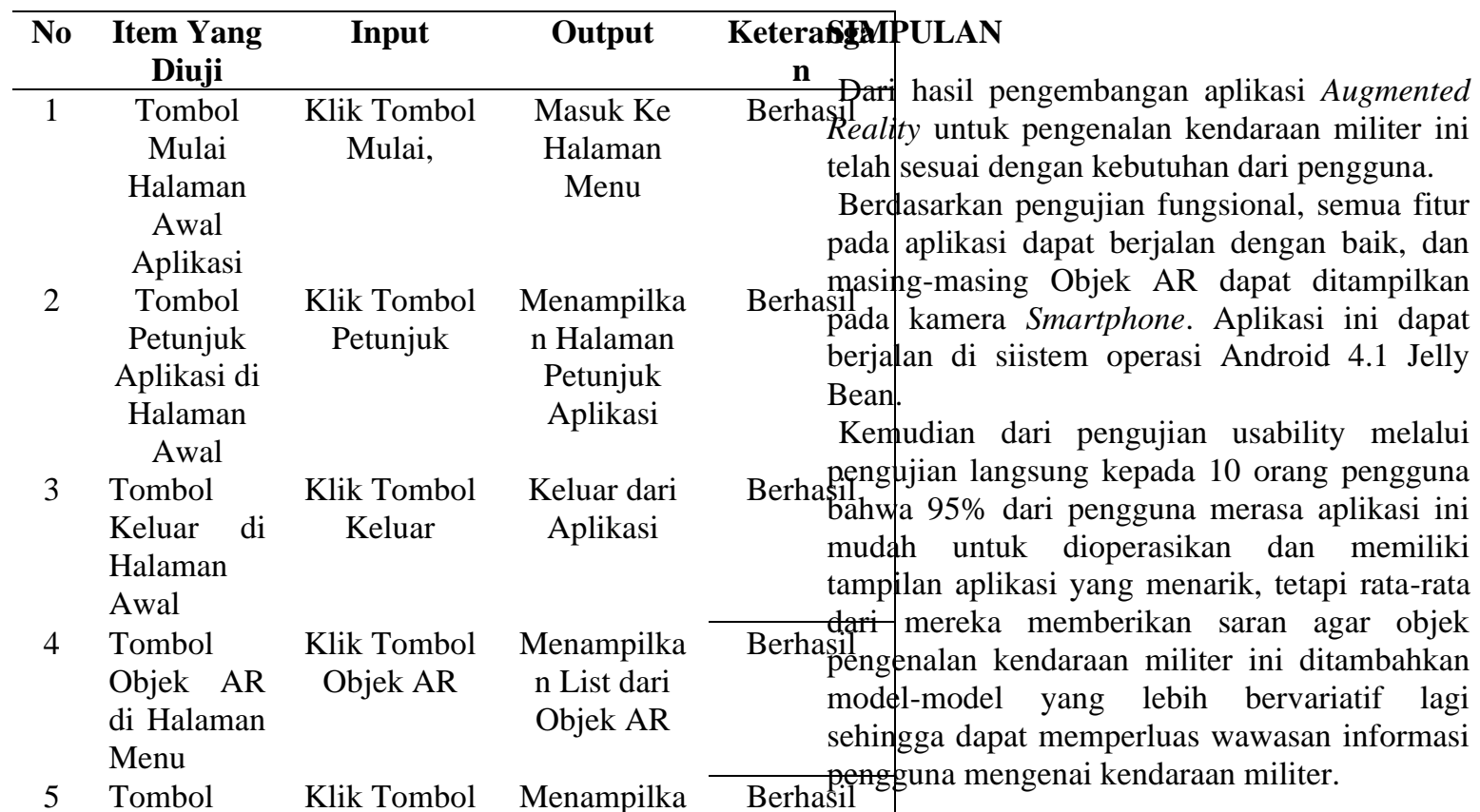

Ensikloped Ensiklopedia n Halaman

ia di Ensiklopedia

Halaman

Menu

6 Tombol

Halaman

Utama di

Halaman

Menu

7 Tombol

Objek

Kendaraan

di Menu

Objek AR

8 Tombol

Objek

Ensikloped

ia

$\begin{array}{cc}\text { Klik Tombol } & \text { Kembali ke } \\ \text { Halaman } & \text { Menu }\end{array}$

Kendaraan

di Menu

Ensikloped

ia

$\begin{array}{cc}\text { Klik Tombol } & \text { Masing- } \\ \text { Objek } & \text { Masing } \\ \text { Kendaraan } & \text { Tombol } \\ & \text { Menampilka } \\ & \text { n Objek AR } \\ \text { Klik Tombol } & \text { Masing- } \\ \text { Objek } & \text { Masing } \\ \text { Kendaraan } & \text { Tombol } \\ & \text { Menampilka } \\ & \text { n Informasi } \\ & \text { Kendaraan }\end{array}$

Dari tabel diatas menunjukkan Input dan Output pada pengujian setiap tombol pada halaman aplikasi untuk menampilkan halaman sesuai dengan fungsi tombol. Hasil diatas menunjukkan bahwa setiap percobaan tombol berhasil menampilkan tampilan menunya. Pengujian Aplikasi ini dilakukan di Smartphone Samsung Galaxy S7 Edge dengan sistem Operasi Android Orea 8.1, dan Ram 4GB. Target sistem operasi untuk aplikasi ini dapat

\section{DAFTAR PUSTAKA}

[1] K. C. Brata and A. H. Brata, "Pengembangan Aplikasi Mobile

Berhasil Augmented Reality untuk Mendukung Pengenalan Koleksi Museum," J. Teknol. Inf. dan Ilmu Komput., vol. 5, no. 3, p. 347, 2018.

[2] I. D. Perwitasari, "Teknik Marker Based

Berhasil Tracking Augmented Reality untuk Visualisasi Anatomi Organ Tubuh Manusia Berbasis Android," INTECOMS J. Inf. Technol. Comput. Sci., vol. 1, no. 1, pp. 8$18,2018$.

Beş̧аsil Unity3D, “Unity Engine,” 2019. [Online]. Available: https://unity3d.com/getunity/download. [Accessed: 20-Dec-2019].

[4] Unity Asset Store, "Unity Asset Store," 2019. [Online]. Available: https://assetstore.unity.com/packages/templa tes/packs/vuforia-core-samples-99026. [Accessed: 20-Dec-2019].

[5] Vuforia, "Vuforia Developer Portal," 2019. [Online]. Available: https://developer.vuforia.com/vui/develop/. [Accessed: 20-Dec-2019]. 